\title{
Identification of Novel Protein-Ligand Interactions by Exon Microarray Analysis of Yeast Surface Displayed cDNA Library Selection Outputs
}

\section{Scott Bidlingmaier and Bin Liu}

\begin{abstract}
Yeast surface display is widely utilized to screen large libraries for proteins or protein fragments with specific binding properties. We have previously constructed and utilized yeast surface displayed human cDNA libraries to identify protein fragments that bind to various target ligands. Conventional approaches employ monoclonal screening and sequencing of polyclonal outputs that have been enriched for binding to a target molecule by several rounds of affinity-based selection. Frequently, a small number of clones will dominate the selection output, making it difficult to comprehensively identify potentially important interactions due to low representation in the selection output. We have developed a novel method to address this problem. By analyzing selection outputs using high-density human exon microarrays, the full potential of selection output diversity can be revealed in one experiment. FACS-based selection using yeast surface displayed human cDNA libraries combined with exon microarray analysis of the selection outputs is a powerful way of rapidly identifying protein fragments with affinity for any soluble ligand that can be fluorescently detected, including small biological molecules and drugs. In this report we present protocols for exon microarray-based analysis of yeast surface display human cDNA library selection outputs.
\end{abstract}

\section{Keywords}

Yeast surface display; cDNA library; Exon microarray; Phosphatidylinositide; Novel nuclear phosphatidylinositide-binding proteins

\section{Introduction}

Identifying proteins that interact with small bioactive molecules such as phosphatidylinositides is an important, but often challenging and rate-limiting step in understanding cellular signaling pathways. Using yeast surface display techniques, heterologous protein fragments can be efficiently displayed on the surface of the Saccharomyces cerevisiae yeast cell as C-terminal fusions to the yeast a-agglutinin subunit, Aga2p [1] and this technology has been extensively utilized in protein engineering applications such as antibody affinity maturation and epitope mapping [2-5]. We have previously described the construction of large $\left(2 \times 10^{7}\right)$ yeast surface-displayed human protein fragment libraries [6-8]. When coupled with fluorescence-activated cell sorting 
(FACS), yeast surface-displayed human protein fragment libraries can theoretically be used to identify protein fragments with affinity for any soluble molecule that can be fluorescently detected. These libraries have been used to identify human protein fragments with affinity for tyrosine-phosphorylated peptides [6], tumor-targeting antibodies [9], and phosphatidylinositides (PtdIns) [7].

Often a small number of clones become dominant during selection, making it likely that rare binding clones in the selection output will be missed by monoclonal screening. To capture the full diversity of yeast surface display selection outputs, we have developed methods using high-density human exon microarrays (see Fig. 1 for method outline). We applied these methods to PtdIns-binding enriched polyclonal yeast selection outputs that had been previously analyzed by standard monoclonal screening and sequencing. In addition to the nine PtdIns-binding protein fragments previously identified by monoclonal screening and sequencing [7], we identified an additional 17 novel PtdIns-binding protein fragments [10] (Table 1). Our results suggest that affinity-based selections with yeast human cDNA display libraries coupled with comprehensive analysis of the outputs using DNA microarrays is a rapid and efficient method for identifying protein interactions. In this report we describe protocols for the analysis of yeast surface display human cDNA library selection outputs using human exon microarrays.

\section{Materials}

\subsection{Plasmid Recovery}

1. Polyclonal yeast surface display selection outputs (see Note 1).

2. $10 \times$ SD-CAA for making plates: $70 \mathrm{~g}$ yeast nitrogen base w/o amino acids, $50 \mathrm{~g}$ Bacto casamino acids, $100 \mathrm{~g}$ dextrose; bring the volume to $500 \mathrm{~mL}$ with $\mathrm{ddH}_{2} \mathrm{O}$ and filter-sterilize.

3. SD-CAA plates: $5.4 \mathrm{~g} \mathrm{Na}_{2} \mathrm{HPO}_{2}, 7.4 \mathrm{~g} \mathrm{NaH}_{2} \mathrm{PO}_{4}, 17 \mathrm{~g}$ agar. Bring the volume to $900 \mathrm{~mL}$ with $\mathrm{ddH}_{2} \mathrm{O}$, autoclave to sterilize, let the agar cool until it is cool enough to touch, add $100 \mathrm{~mL} 10 \times \mathrm{SD}-\mathrm{CAA}$, mix and pour into plates $(100$ or $150 \mathrm{~mm})$ and allow to cool at RT, and store the plates at $4{ }^{\circ} \mathrm{C}$ until ready to use.

4. Acid-washed glass beads (Sigma).

5. Spin miniprep kit (Qiagen).

6. 10G Supreme electrocompetent cells (Lucigen).

7. Transformation recovery medium (supplied with $10 \mathrm{G}$ Supreme cells).

8. $1 \mathrm{~mm}$ Electroporation cuvettes (Molecular BioProducts).

9. Electroporators (Eppendorf 2510, Bio-Rad Gene Pulser II).

\footnotetext{
${ }^{1}$ We have previously described protocols for the construction of yeast surface-displayed human cDNA libraries [4, 8] and their application to identify human protein fragments with affinity for tyrosine-phosphorylated peptides [2], tumor-targeting antibodies [5], and phosphatidylinositides [3]. As a starting point for exon microarray analysis we use polyclonal yeast surface displayed human cDNA selection outputs enriched for clones that bind to the desired target ligand. We enrich for target binding by FACS until the fraction of binding clones in the polyclonal outputs is greater than $90 \%$.
} 
10. $2 \times$ YT: $16 \mathrm{~g}$ tryptone, $10 \mathrm{~g}$ yeast extract, $5 \mathrm{~g} \mathrm{NaCl}$, bring volume to $1 \mathrm{~L}$ with $\mathrm{ddH}_{2} \mathrm{O}$, adjust $\mathrm{pH}$ to 7.0 , and sterilize by autoclaving.

11. $1,000 \times$ ampicillin: $1 \mathrm{~g}$ ampicillin, add $\mathrm{ddH}_{2} \mathrm{O}$ to $10 \mathrm{~mL}$, sterilize by filtration and aliquot, and store aliquots at $-20{ }^{\circ} \mathrm{C}$.

12. $150 \mathrm{~mm} 2 \times \mathrm{YT}$ ampicillin plates: $16 \mathrm{~g}$ tryptone, $10 \mathrm{~g}$ yeast extract, $5 \mathrm{~g} \mathrm{NaCl}, 17 \mathrm{~g}$ agar, bring volume to $1 \mathrm{~L}$ with $\mathrm{ddH}_{2} \mathrm{O}$, adjust $\mathrm{pH}$ to 7.0 , sterilize by autoclaving, let cool until not too hot to touch and add $1 \mathrm{~mL} 1,000 \times$ ampicillin.

13. Maxiprep kit (Qiagen).

\subsection{Preparation of Biotinylated cRNA Probes}

1. Plasmids recovered from polyclonal selection output (described in Subheading 3.1).

2. XhoI restriction enzyme.

3. Notl restriction enzyme.

4. $10 \times$ React 3 .

5. Qiagen spin prep kit.

6. Biotin-16-UTP.

7. Ambion MAXIscript T7 kit (Ambion).

8. RNeasy Mini Kit (Qiagen).

\subsection{Exon Microarray Data Analysis}

1. Affymetrix GeneChip ${ }^{\circledR}$ Human Exon 1.0 ST Array (Affymetrix) (see Note 2).

2. Affymetrix Expression Console software (Affymetrix) (see Note 3).

3. Integrated Genome Browser software [7] (see Note 4).

4. Excel (Microsoft).

\subsection{Recovery of Putative Binding Clones}

1. cDNA-specific primer sets designed using the exon microarray data (see Note 5).

2. pYD1-specific primers: pYD1 Forward 5'-AGTAACGTTTGTCAGTAATTGC-3', pYD1 Reverse 5'-GTCGATTTTGTTACATCTACAC-3' ( see Note 6).

3. $10 \times$ PCR buffer.

\footnotetext{
${ }^{2}$ The GeneChip ${ }^{\circledR}$ Human Exon 1.0 ST Array has 1.4 million total probe sets (approximately four probes per exon and roughly 40 probes per gene). The probes tiled on the array are designed in the antisense orientation, requiring sense-strand labeled targets to be hybridized to the array. For more information about the GeneChip ${ }^{\circledR}$ Human Exon 1.0 ST Array consult the Affymetrix website. ${ }^{3}$ Expression Console Software is used to analyze microarray data and is freely available on the Affymetrix website.

${ }^{4}$ The Integrated Genome Browser is an application that allows the graphic visualization of exon microarray-generated data in the context of an annotated human genome.

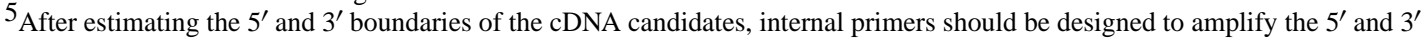
cDNA/vector junctions. We find it convenient for downstream gel isolation to design the primers to produce an approximately $500 \mathrm{bp}$ product.

${ }^{6}$ If a yeast display vector other than pYD1 is utilized then different primers will need to be designed.
} 
4. dNTPs.

5. Taq polymerase.

6. Primers for sequencing: Gap5 5'-TTAAGCTTCTGCAGGCTAGTG-3', Gap3 5'GTTAGGGATAGGCTTACCTTC-3' (see Note 6).

7. Primer sets based on the $5^{\prime}$ and $3^{\prime}$ boundaries of the cDNA inserts with added EcoRI overhangs for cloning into pYD1 (see Note 7).

8. EcoRI restriction enzyme and $10 \times$ EcoRI buffer.

9. pYD1 or suitable yeast display vector.

10. T4 DNA ligase and $10 \times$ ligation buffer.

11. Chemically competent $E$. coli cells.

12. Heat block at $42{ }^{\circ} \mathrm{C}$.

13. $1,000 \times$ Ampicillin: $1 \mathrm{~g}$ ampicillin, add $\mathrm{ddH}_{2} \mathrm{O}$ to $10 \mathrm{~mL}$, sterilize by filtration and aliquot, and store aliquots at $-20^{\circ} \mathrm{C}$.

14. $100 \mathrm{~mm} 2 \times$ YT ampicillin plates: $16 \mathrm{~g}$ tryptone, $10 \mathrm{~g}$ yeast extract, $5 \mathrm{~g} \mathrm{NaCl}, 17 \mathrm{~g}$ agar, bring volume to $1 \mathrm{~L}$ with $\mathrm{ddH}_{2} \mathrm{O}$, adjust $\mathrm{pH}$ to 7.0 , sterilize by autoclaving, let cool until not too hot to touch and add $1 \mathrm{~mL} 1,000 \times$ ampicillin and pour.

15. Spin miniprep kit (Qiagen).

16. S. cerevisiae strain EBY100 (MATa GAL1-AGA1::URA3 ura3-52 trp1 leu2 $\Delta 1$ his3 $\Delta 200$ pep4::HIS3 prb1 $\Delta 1.6 \mathrm{R}$ can1 GAL).

17. YPD: $10 \mathrm{~g}$ of yeast extract, $20 \mathrm{~g}$ of bacteriological peptone, $20 \mathrm{~g}$ dextrose, bring volume to $1 \mathrm{~L}$ with $\mathrm{ddH}_{2} \mathrm{O}$, and filter-sterilize.

18. $50 \%$ PEG-3350: 250 g PEG-3350, bring volume to $500 \mathrm{~mL}$ with $\mathrm{ddH}_{2} \mathrm{O}$, and filter-sterilize.

19. $1 \mathrm{M}$ lithium acetate: $33 \mathrm{~g}$ lithium acetate, bring volume to $500 \mathrm{~mL}$ with $\mathrm{ddH}_{2} \mathrm{O}$, and filter-sterilize.

20. $10 \times$ SD-CAA for making plates: $70 \mathrm{~g}$ yeast nitrogen base without amino acids, $50 \mathrm{~g}$ Bacto casamino acids, $100 \mathrm{~g}$ dextrose, bring volume to $500 \mathrm{~mL}$ with $\mathrm{ddH}_{2} \mathrm{O}$, and filter-sterilize.

21. SD-CAA plates: $5.4 \mathrm{~g} \mathrm{Na}_{2} \mathrm{HPO}_{2}, 7.4 \mathrm{~g} \mathrm{NaH}_{2} \mathrm{PO}_{4}, 17 \mathrm{~g}$ agar, bring volume to 900 $\mathrm{mL}$ with $\mathrm{ddH}_{2} \mathrm{O}$ and autoclave, let cool until not too hot to touch and add $100 \mathrm{~mL}$ $10 \times$ SD-CAA, pour plates of desired size $(100$ or $150 \mathrm{~mm})$ and allow to cool at RT, and store plates at $4{ }^{\circ} \mathrm{C}$ until ready to use (see Note 8).

${ }^{7}$ Design primers to amplify the candidate cDNAs based on the sequencing data. Take care to ensure that the cDNA coding regions will be in frame with Aga2 after cloning into the display vector.

${ }^{8}$ Antibiotics (ampicillin and/or tetracycline) can be added to the plates if contamination is an issue. 


\subsection{FACS}

1. $2 \times$ SR-CAA yeast growth media: $20 \mathrm{~g}$ raffinose, $14 \mathrm{~g}$ yeast nitrogen base, $10 \mathrm{~g}$ Bacto casamino acids, $5.4 \mathrm{~g} \mathrm{Na}_{2} \mathrm{HPO}_{4}, 7.4 \mathrm{~g} \mathrm{NaH}_{2} \mathrm{PO}_{4}$, bring volume to $1 \mathrm{~L}$ with $\mathrm{ddH}_{2} \mathrm{O}$, and filter-sterilize.

2. $20 \%$ Galactose: $100 \mathrm{~g}$ galactose; bring the volume to $500 \mathrm{~mL}$ with $\mathrm{ddH}_{2} \mathrm{O}$ and filter-sterilize.

3. PBS: $8 \mathrm{~g}$ of NaCl, $0.2 \mathrm{~g}$ of $\mathrm{KCl}, 1.44 \mathrm{~g}$ of $\mathrm{Na}_{2} \mathrm{HPO}_{4}, 0.24 \mathrm{~g}$ of $\mathrm{KH}_{2} \mathrm{PO}_{4}$, bring the volume to $1 \mathrm{~L}$ with $\mathrm{ddH}_{2} \mathrm{O}$, adjust $\mathrm{pH}$ to 7.4 , and sterilize by autoclaving or filtration.

4. Biotinylated or fluorescently labeled target molecules (see Note 9).

5. Mouse anti-Xpress (Invitrogen).

6. Goat anti-mouse-647 (Jackson ImmunoResearch).

7. Streptavidin-PE (SA-PE) (Invitrogen).

\section{Methods}

Protocols detailing the construction and use of yeast surface-displayed human protein fragment libraries for FACS-based enrichment of protein fragments with affinity for various target ligands have been described previously $[8,11]$. Here we describe protocols for the comprehensive analysis of enriched polyclonal yeast surface display selection outputs using exon microarrays. It is assumed that a core facility or commercial service will be performing the chip hybridization and data collection steps and therefore protocols for these steps are not described. Additionally, since the Affymetrix Expression Console software used to process the raw chip data is frequently updated, detailed protocols for the software-based data processing will not be described. Instead, a brief outline of the data analysis we performed will be presented. Affymetrix provides detailed instruction manuals and video tutorials for the current version of the Expression Console software package on their website. The core facility or commercial service provider may also offer data analysis services. The methods below are divided into five categories: Plasmid Recovery From Polyclonal Yeast Display Selection Outputs (Subheading 3.1); Preparation of Biotinylated cRNA probes (Subheading 3.2); Exon Microarray Data Analysis (Subheading 3.3); Recovery of putative binding clones (Subheading 3.4); Testing candidate binding clones by FACS (Subheading 3.5).

\subsection{Plasmid Recovery from Poly clonal Yeast Display Selection Outputs}

1. Prewarm and dry one $150 \mathrm{~mm}$ SD-CAA plate for each selection output to be analyzed in a $30^{\circ} \mathrm{C}$ incubator. Thaw freezer stocks of the selection outputs at RT and evenly spread $100 \mu \mathrm{L}$ of each selection output on a $150 \mathrm{~mm}$ SD-CAA plate. Incubate the plates upside down at $30{ }^{\circ} \mathrm{C}$ for $1-2$ days (see Note 10).

\footnotetext{
9 It is best to use the same labeled target reagents that were utilized during the selection process.

${ }^{10}$ The yeast should form an almost continuous layer of colonies. If the number of colonies seems too low to cover the expected diversity, more volume can be plated.
} 
2. Add $5 \mathrm{~mL}$ of $2 \times$ SR-CAA to each plate, resuspend the cells by scraping with a flame-sterilized spreader, and then collect the resuspended cells by pipetting. Recover an approximately $200 \mu \mathrm{L}$ yeast cell pellet by centrifugation and wash twice with $\mathrm{ddH}_{2} \mathrm{O}$.

3. Resuspend the pellet in $400 \mu \mathrm{L}$ Qiagen buffer P1 (see Note 11) and add approximately $400 \mu \mathrm{L}$ glass beads (the beads should be about $50 \%$ of the total volume). Vortex at high speed for $10 \mathrm{~min}$ and remove $250 \mu \mathrm{L}$ of the cell slurry (leaving the glass beads behind) to a clean tube.

4. Add $250 \mu \mathrm{L}$ buffer P2, gently mix by inverting, and incubate at RT for 5 min.

5. Add $350 \mu \mathrm{L}$ buffer $\mathrm{N} 3$ (a cloudy precipitate will form) and spin at $16,000 \times g$ in a microcentrifuge for $15 \mathrm{~min}$.

6. Apply supernatant to a Qiagen spin miniprep column and spin at $16,000 \times g$ for 1 min. Discard flow-through.

7. Add $750 \mu \mathrm{L}$ buffer PE and spin at $16,000 \times g$ for $1 \mathrm{~min}$. Discard flow-through and spin at $16,000 \times g$ for 2 min to remove residual buffer PE. Replace collection tube

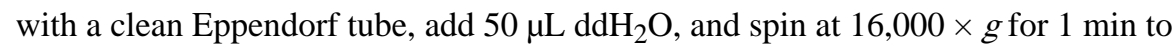
elute.

8. Prewarm transformation recovery medium at $37^{\circ} \mathrm{C}$. Place electroporation cuvettes on ice. Thaw $10 \mathrm{G}$ supreme cells completely on ice (10-20 min) and aliquot $25 \mu \mathrm{L}$ of cells for each output to be recovered to prechilled $1.5 \mathrm{~mL}$ Eppendorf tubes on ice. Add $4 \mu \mathrm{L}$ of each of the polyclonal output yeast plasmid preps to the tubes with cells and stir gently without pipetting up and down.

9. Transfer $25 \mu \mathrm{L}$ of the cell/ligation mixture to the chilled electroporation cuvettes, and electroporate using the following conditions (see Note 12).

$10 \mu \mathrm{F}$

$600 \Omega$

$1,800 \mathrm{~V}$

Immediately add approximately $1 \mathrm{~mL}$ of the prewarmed recovery medium to the cuvette, resuspend the cells, and transfer to $17 \mathrm{~mm}$ culture tubes.

10. Incubate tubes at $37{ }^{\circ} \mathrm{C}$ with shaking at $250 \mathrm{rpm}$ for $1 \mathrm{~h}$. Dry $2 \times \mathrm{Y}$ T-ampicillin plates at $37^{\circ} \mathrm{C}$ while transformations are recovering.

11. Plate $1 / 10,000$ of each transformation on a $2 \times$ YT-ampicillin plate for titering, and plate the remaining transformation cultures on three more plates at approximately $350 \mathrm{~mL} /$ plate. Incubate the plates overnight at $37^{\circ} \mathrm{C}$ ( see Note 13).

\footnotetext{
${ }^{11}$ The method we describe is based on the Qiagen spin miniprep kit. The buffers used (P1, P2, N3, and EB) are provided in the kit.

${ }^{12} \mathrm{We}$ use an Eppendorf 2510 electroporator. Other electroporators should work similarly using the same settings. The time constant should be $3.5-4.5 \mathrm{~ms}$.

${ }^{13}$ There should be at least 100 colonies on the $1 / 10,000$ titer plate. If the transformation efficiency is low, it will need to be repeated.
} 
12. Add $3 \mathrm{~mL} 2 \times \mathrm{YT}+$ ampicillin to each of the plates, resuspend cells with a flamesterilized spreader, and collect by pipetting.

13. Prepare bacterial freezer stocks of the library by mixing $0.5 \mathrm{~mL} 50 \%$ glycerol and $0.5 \mathrm{~mL}$ of the resuspended transformants in a cryotube and store at $-80{ }^{\circ} \mathrm{C}$.

14. Prepare several minipreps or a Qiagen maxiprep using the remaining resuspended transformants according to manufacturer's protocols. Determine the concentration of the library DNA prep using a spectrophotometer.

\subsection{Preparation of Biotinylated cRNA Probes}

1. Set up the following digestions:

$4 \mu \mathrm{L} 10 \times$ React 3

$10 \mu \mathrm{g}$ recovered selection output plasmid

$2 \mu \mathrm{L}$ Not $\mathrm{I}$

Bring volume to $40 \mu \mathrm{L}$ with $\mathrm{ddH}_{2} \mathrm{O}$

$4 \mu \mathrm{L} 10 \times$ React 3

$10 \mu \mathrm{g}$ recovered selection output plasmid

$2 \mu \mathrm{L} X h o \mathrm{I}$

Bring volume to $40 \mu \mathrm{L}$ with $\mathrm{ddH}_{2} \mathrm{O}$

Incubate at $37^{\circ} \mathrm{C}$ for $3 \mathrm{~h}$ (see Note 14).

2. Run the digestions on a $0.75 \%$ agarose gel, cut out linearized bands with a clean razor blade, and isolate DNA using Qiagen gel isolation kit following manufacturer's protocols. Elute in $50 \mu \mathrm{L}$ EB buffer, combine the gel purified NotI and $\mathrm{XhoI}$ digestions, and measure the concentration with a spectrometer.

3. Thaw the frozen reagents from Ambion MAXIscript T7 kit. Vortex the 10x Transcription Buffer and ribonucleotide solutions until they are completely in solution. Once they are thawed, store the ribonucleotides on ice, but keep the $10 \times$ Transcription Buffer at room temp. Assemble transcription reaction at room temperature, adding the $10 \times$ Transcription Buffer after the water and template DNA are already in the tube:

\begin{tabular}{|ll|}
\hline Nuclease-free water to & $20 \mu \mathrm{L}$ \\
\hline DNA template & $1 \mu \mathrm{g}$ \\
\hline $10 \times$ transcription buffer & $2 \mu \mathrm{L}$ \\
\hline $10 \mathrm{mM}$ ATP & $1 \mu \mathrm{L}$ \\
\hline $10 \mathrm{mM} \mathrm{CTP}$ & $1 \mu \mathrm{L}$ \\
\hline
\end{tabular}

\footnotetext{
${ }^{14}$ We use two different enzymes to linearize the plasmid to minimize the chances of cutting in the cDNA insert.
} 


\begin{tabular}{|ll|}
\hline $10 \mathrm{mM}$ GTP & $1 \mu \mathrm{L}$ \\
\hline $10 \mathrm{mM}$ UTP & $0.6 \mu \mathrm{L}$ \\
\hline $10 \mathrm{mM}$ biotin-16-UTP & $0.4 \mu \mathrm{L}$ \\
\hline T7 enzyme mix & $2 \mu \mathrm{L}$ \\
\hline
\end{tabular}

4. Incubate for $1 \mathrm{~h}$ at $37^{\circ} \mathrm{C}$

5. Add $1 \mu \mathrm{L}$ TURBO DNase, mix well, and incubate at $37^{\circ} \mathrm{C}$ for $15 \mathrm{~min}$

6. Purify the biotinylated cRNA probe from the in vitro transcription reaction using the RNeasy Mini Kit according to manufacturer's instructions and quantitate using spectrophotometer (see Note 15).

\subsection{Exon Microarray Data Analysis}

Since it is assumed that that probe hybridization and data collection will be performed by a core facility or commercial service, detailed protocols for the exon chip hybridization and data collection will not be presented here. Briefly, the biotinylated cRNA probes were fragmented by sonication and $5 \mu \mathrm{g}$ of each was hybridized to an Affymetrix GeneChip ${ }^{\circledR}$ Human Exon 1.0 ST Array and scanned with an Affymetrix GeneChip Scanner 3000 (Affymetrix) according to manufacturer's instructions at a core facility.

Although it is beyond the scope of this review to provide a detailed protocol for the software-based data analysis, a brief outline of the strategy we used to analyze the raw data with Affymetrix Expression Console and Integrated Genome Browser software [12] and generate a list of binding candidates for validation is presented below. Please refer to the Affymetrix website for detailed manuals and tutorials that describe use of current software versions.

1. Process .cel files using Expression Console software.

2. Generate list of ranked probeset intensities using Expression Console.

3. Calculate gene expression level using Expression Console and transfer annotated results to excel.

4. Visualize .chp files using Integrated Genome Browser software and examine high scoring genes and top probeset intensities. Look for genes with multiple continuous high-scoring probesets within the exons (see Fig. 2 for examples) (see Note 16).

5. Make a list of candidate binders and estimate the boundaries of the cDNA for each candidate based on the probeset intensity values (see Note 17).

\footnotetext{
${ }^{15}$ We hybridized $5 \mu \mathrm{g}$ of each biotinylated cRNA probe to the exon array chip. If less than this amount is recovered after purification, the in vitro transcription reaction will need to be repeated.

${ }^{16}$ There will be some background from the common vector sequences in the in vitro transcribed probes. If data from several selection outputs is simultaneously visualized in the Integrated Genome Browser, it is easy to identify probesets with a high nonspecific background signal.

${ }^{17}$ The sequences of the high signal intensity probes within a candidate gene can be recovered from within the Integrated Genome Browser.
} 


\subsection{Recovery of Putative Binding Clones}

1. Design a forward and reverse primer located near the middle of each predicted candidate gene cDNA (see Note 18).

2. Set up standard PCR reactions using candidate cDNA-specific and vector-specific (pYD1 Forward and pYD1 Reverse) primers and $1 \mathrm{ng}$ of the appropriate selection output plasmid prep as template.

3. Run PCR reactions on $1.5 \%$ agarose gel, cut out bands with a clean razor blade, and isolate DNA using Qiagen gel isolation kit following manufacturer's protocols. Elute in $50 \mu \mathrm{L}$ EB buffer or $\mathrm{ddH}_{2} \mathrm{O}$.

4. Sequence purified PCR products using the appropriate primer (Gap5 for PCRs done with pYD1 Forward or Gap3 for PCRs done with pYD1 Reverse).

5. Analyze sequence data to define the precise $5^{\prime}$ and $3^{\prime} \mathrm{cDNA}$ insert boundaries and determine if the cDNA encoded protein is in-frame with AGA2 in the pYD1 yeast display vector.

6. Design new primer sets based on the newly determined $5^{\prime}$ and $3^{\prime}$ boundaries of the cDNA inserts, adding EcoRI overhangs to facilitate cloning (see Note 7).

7. PCR amplify the cDNA inserts using the cDNA-specific primer sets and gel purify.

8. Digest $\mathrm{pYD} 1$ and the candidate cDNA PCR products with EcoRI, purify, ligate, transform, miniprep colonies using standard molecular biology procedures, and sequence to confirm using the Gap5 sequencing primer.

9. Inoculate a $5 \mathrm{~mL}$ YPD culture with EBY 100 and grow overnight with shaking at $30^{\circ} \mathrm{C}$ and $200 \mathrm{rpm}$.

10. Determine concentration of the overnight yeast culture by measuring the OD600 of a 1:20 dilution using a spectrophotometer $\left(1 \mathrm{OD} 600=2 \times 10^{7} / \mathrm{mL}\right)$.

11. Use the overnight culture to inoculate a culture in YPD (the inoculation volume should be at least $1 \mathrm{~mL} /$ transformation) at $0.5 \mathrm{OD} 600$ and incubate at $30^{\circ} \mathrm{C}, 200$ rpm for $4-5 \mathrm{~h}$ (at least two cell divisions).

12. For each transformation, pellet $1 \mathrm{~mL}$ of the $\mathrm{EBY} 100$ culture by centrifugation at $3,000 \times g$ for $3 \mathrm{~min}$, wash with $1 \mathrm{~mL}$ sterile $\mathrm{ddH}_{2} \mathrm{O}$, and remove $\mathrm{ddH}_{2} \mathrm{O}$.

13. To each tube of cells, add the following in this order:

$240 \mu \mathrm{L} 50 \%$ PEG-3350

$36 \mu \mathrm{L} 1.0 \mathrm{M}$ lithium acetate

$5 \mu \mathrm{g}$ plasmid (candidate cDNAs cloned into pYD1).

Bring volume to $360 \mu \mathrm{L}$ with sterile $\mathrm{ddH}_{2} \mathrm{O}$.

\footnotetext{
18 We designed the primers to produce products about 500 bp in size for efficient PCR and gel-based purification.
} 
14. Vortex transformation mix vigorously and incubate tubes at $42{ }^{\circ} \mathrm{C}$ in a water bath for $40 \mathrm{~min}$.

15. Spin transformation tubes at top speed for $30 \mathrm{~s}$ and remove transformation mix. Resuspend pellet in $100 \mu \mathrm{L}$ sterile $\mathrm{ddH}_{2} \mathrm{O}$ and plate on prewarmed SD-CAA plates. Incubate the plates inverted at $30^{\circ} \mathrm{C}$ for 3-4 days until colonies grow. Clones can be stored in SD-CAA $+20 \%$ glycerol at $-80{ }^{\circ} \mathrm{C}$.

\subsection{Testing Candidate Binding Clones by FACS}

1. Inoculate $2 \mathrm{~mL} 2 \times$ SRG-CAA $(2 \times$ SR-CAA $+2 \%$ galactose) cultures with yeast colonies from candidate cDNA transformations and grow for at least $16 \mathrm{~h}$ with shaking at $30^{\circ} \mathrm{C}$.

2. Pellet $200 \mu \mathrm{L}$ of the overnight cultures using a tabletop microfuge and wash twice with $1 \mathrm{~mL}$ PBS.

3. Incubate yeast for $1 \mathrm{~h}$ at room temperature with $100 \mu \mathrm{L}$ of an appropriate concentration of biotinylated or fluorescently labeled target molecule (see Note 9) and mouse anti-Xpress antibody (1/1,000 dilution of stock solution) in PBS (see Note 19).

4. Wash yeast twice with $1 \mathrm{~mL}$ PBS and incubate with $100 \mu \mathrm{L}$ 1/1,000 SA-PE and 1/1,000 Alexa fluor 647-conjugated anti-mouse secondary antibody in PBS for 30 $\min$.

5. Wash twice with $1 \mathrm{~mL}$ PBS and analyze the yeast by FACS.

\section{Acknowledgments}

The work is supported by grants from the National Institute of Health (R01 CA171315, R01 CA118919, and R01 CA129491).

\section{References}

1. Boder ET, Wittrup KD. Yeast surface display for screening combinatorial polypeptide libraries. Nat Biotechnol. 1997; 15(6):553-557. [PubMed: 9181578]

2. Feldhaus MJ, Siegel RW, Opresko LK, et al. Flow-cytometric isolation of human antibodies from a nonimmune Saccharomyces cerevisiae surface display library. Nat Biotechnol. 2003; 21(2):163170. [PubMed: 12536217]

3. Cochran JR, Kim Y-S, Olsen MJ, et al. Domain-level antibody epitope mapping through yeast surface display of epidermal growth factor receptor fragments. J Immunol Methods. 2004; 287(12):147-158. [PubMed: 15099763]

4. Gai SA, Wittrup KD. Yeast surface display for protein engineering and characterization. Curr Opin Struct Biol. 2007; 17(4):467-473. [PubMed: 17870469]

5. Pepper LR, Cho YK, Boder ET, Shusta EV. A decade of yeast surface display technology: where are we now? Comb Chem High Throughput Screen. 2008; 11(2):127-134. [PubMed: 18336206]

6. Bidlingmaier S, Liu B. Construction and application of a yeast surface-displayed human cDNA library to identify post-translational modification-dependent protein-protein interactions. Mol Cell Proteomics. 2006; 5(3):533-540. [PubMed: 16321969]

\footnotetext{
${ }^{19}$ There is an Xpress epitope upstream of the cDNA inserts in the pYD1 yeast display vector allowing the efficiency of surface display to be monitored using and anti-Xpress antibody.
} 
7. Bidlingmaier S, Liu B. Interrogating yeast surface-displayed human proteome to identify small molecule-binding proteins. Mol Cell Proteomics. 2007; 6(11):2012-2020. [PubMed: 17660511]

8. Bidlingmaier S, Liu B. Construction of yeast surface-displayed cDNA libraries. Methods Mol Biol. 2011; 729:199-210. [PubMed: 21365492]

9. Bidlingmaier S, He J, Wang Y, et al. Identification of MCAM/CD146 as the target antigen of a human monoclonal antibody that recognizes both epithelioid and sarcomatoid types of mesothelioma. Cancer Res. 2009; 69(4):1570-1577. [PubMed: 19221091]

10. Bidlingmaier S, Wang Y, Liu Y, et al. Comprehensive analysis of yeast surface displayed cDNA library selection outputs by exon microarray to identify novel protein-ligand interactions. Mol Cell Proteomics. 2011; 10(3) http://www.mcponline.org/content/10/3/M110.005116.

11. Bidlingmaier S, Liu B. Identification of protein/target molecule interactions using yeast surfacedisplayed cDNA libraries. Methods Mol Biol. 2011; 729:211-223. [PubMed: 21365493]

12. Nicol JW, Helt GA, Blanchard SG, et al. The Integrated Genome Browser: free software for distribution and exploration of genome-scale datasets. Bioinformatics. 2009; 25(20):2730-2731. [PubMed: 19654113] 


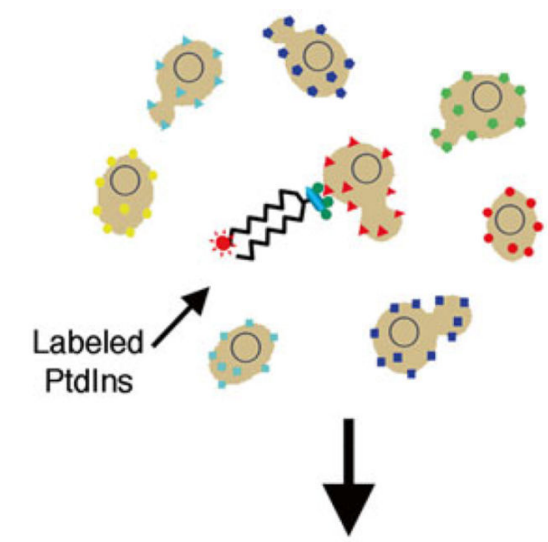

\section{Incubate yeast library displaying human protein fragments with labeled PtdIns and collect binding clones by FACS}

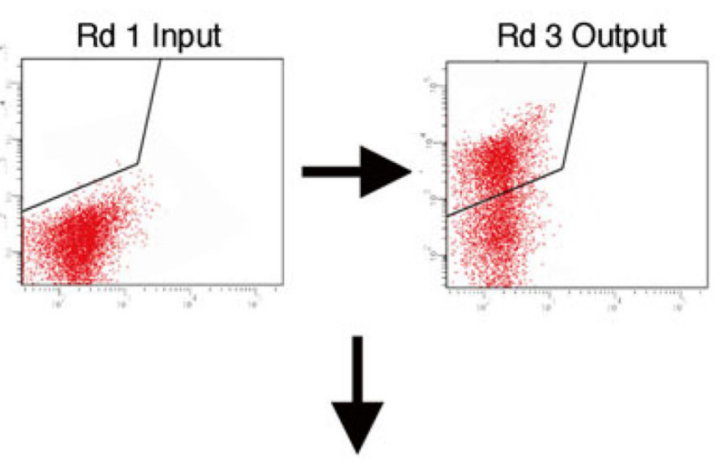

\section{Enrich binding clones through several rounds of FACS}

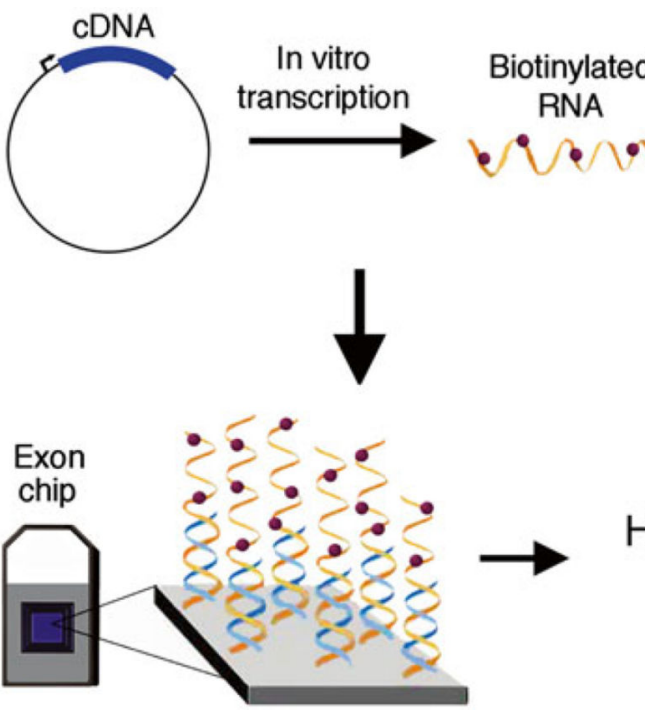

Hybridize biotinylated RNA to exon chip, collect data, and analyze

Fig. 1.

Diagram of procedure for enrichment of clones displaying PtdIns-binding protein fragments and comprehensive exon microarray analysis of polyclonal selection output. A yeast library displaying human protein fragments was incubated with labeled PtdIns and binding yeast clones were enriched through several rounds of FACS. Polyclonal plasmid containing cDNAs encoding PtdIns-binding protein fragments was isolated from the polyclonal selection output and used as a template for in vitro transcription to generate biotin-labeled RNA. The labeled RNA was hybridized to the exon microarray and data was collected and 
analyzed. (This research was originally published in Mol Cell Proteomics [10] () the American Society for Biochemistry and Molecular Biology) 

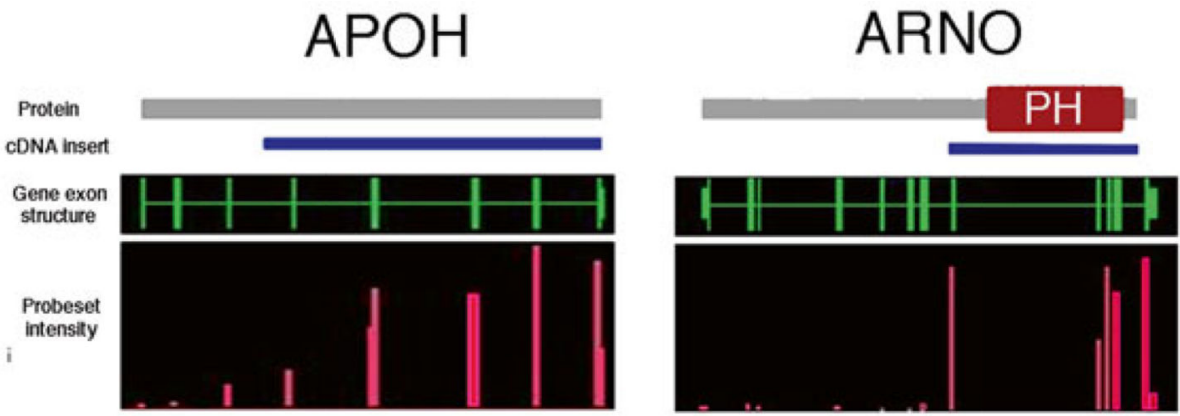

DAB2

GAB2

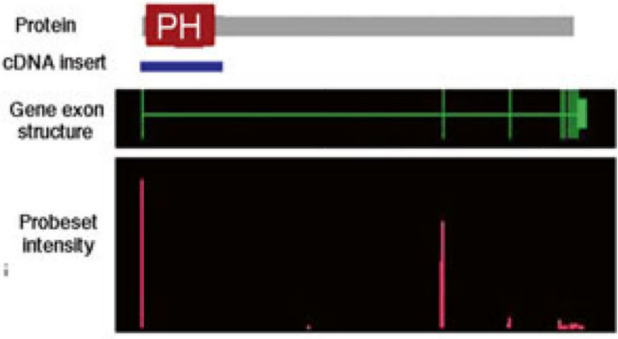

OSBP2

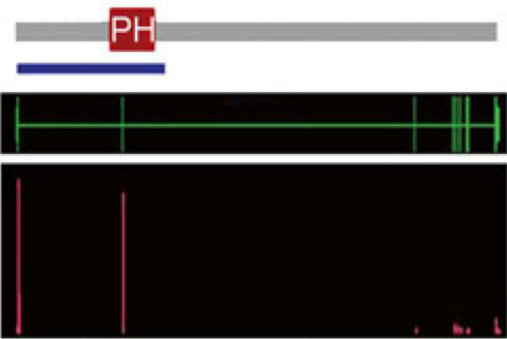

PSD

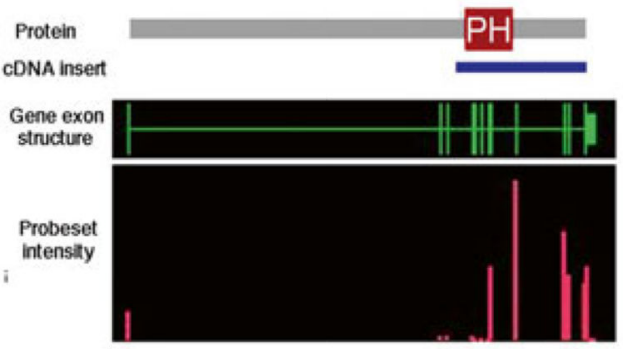

SBF1

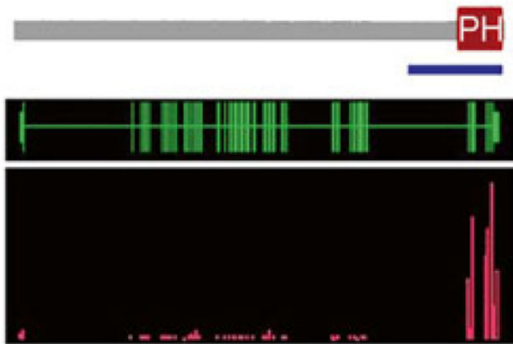

PDK1
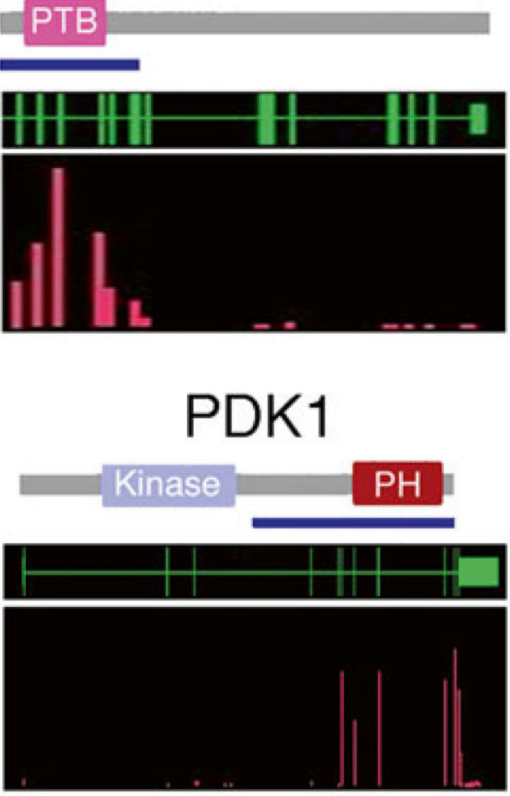

SPTBN2

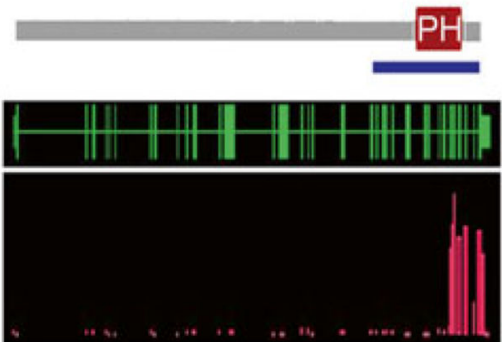

Fig. 2.

Visualization of probeset intensity data collected from an Affymetrix GeneChip ${ }^{\circledR}$ Human Exon 1.0 ST Array hybridized with cRNA probes prepared from polyclonal yeast cDNA display selection outputs enriched for binding to PtdIns [6]. The gene exon structure is shown in green. Intensity values for exon-associated probesets are represented by red bars below the gene exon structure. The exon structure and probeset intensity data is visualized using Integrated Genome Browser software. Grey bars represent the total protein with boxes indicating the location of known functional domains (PH, pleckstrin homology domain; PTB, phosphotyrosine-binding domain). The blue bars below represent the protein fragments encoded by the cDNA inserts determined by sequencing. Since the gene exon structures are interrupted by non-protein coding intronic sequences, they do not precisely align with the proteins depicted above. (This research was originally published in Mol Cell Proteomics [10] (C) the American Society for Biochemistry and Molecular Biology) 


\section{Table 1}

FACS-validated phosphatidylinositide-binding protein fragments identified by exon microarray analysis of yeast surface displayed cDNA library selection outputs. Expressed regions and total aa lengths are shown

\begin{tabular}{|c|c|c|c|}
\hline Protein & Expressed aa & Total aa & PtdIns-binding domain (aa) \\
\hline $\mathrm{APOH}$ & $94-345$ & 345 & \\
\hline ARNO & $226-399$ & 399 & PH (261-386) \\
\hline ATN $1^{a}$ & $1-229$ & 1,190 & \\
\hline CRABP1 $1^{a}$ & $1-137$ & 137 & \\
\hline CRIP1A $^{a}$ & $1-140$ & 164 & \\
\hline DAB2 & $2-221$ & 771 & PTB (36-176) \\
\hline${\text { FAM } 71 B^{a}}^{a}$ & $267-546$ & 605 & \\
\hline GAB2 & $1-125$ & 676 & PH (9-116) \\
\hline HMGN2 ${ }^{a}$ & $6-90$ & 90 & \\
\hline HOXA $5^{a}$ & $206-270$ & 270 & \\
\hline HOXB6 $^{a}$ & $136-224$ & 224 & \\
\hline HOXC6 $^{a}$ & $150-235$ & 235 & \\
\hline HOXD4 $4^{a}$ & $144-255$ & 255 & \\
\hline NUCKS $1^{a}$ & $54-243$ & 243 & \\
\hline OSBP2 & $5-290$ & 915 & PH (185-272) \\
\hline PDK1 & $232-429$ & 429 & PH (330-394) \\
\hline PNPLA7 ${ }^{a}$ & $1,013-1,274$ & 1,317 & \\
\hline $\mathrm{POLS}^{a}$ & $412-542$ & 542 & \\
\hline PSD & $739-1,024$ & 1,024 & PH (758-874) \\
\hline PTPN5 ${ }^{a}$ & $1-60$ & 565 & \\
\hline $\mathrm{RNPS}^{a}{ }^{a}$ & $1-230$ & 305 & \\
\hline SBF1 & $1,638-1,893$ & 1,893 & PH $(1,790-1,890)$ \\
\hline SFRS $^{a}{ }^{a}$ & 409-494 & 494 & \\
\hline SPTBN2 & $2,101-2,390$ & 2,390 & PH $(2,221-2,304)$ \\
\hline $\mathrm{WDR}^{2} 0^{a}$ & $60-260$ & 1,066 & \\
\hline $\mathrm{WNK} 1^{a}$ & $924-1,156$ & 2,382 & \\
\hline
\end{tabular}

a a amino acids, $C 2 \mathrm{C} 2$ domain, $P H$ pleckstrin homology domain, $P T B$ phospho-tyrosine binding domain

${ }^{a}$ PtdIns-binding protein fragments identified by human exon microarray analysis that were missed by monoclonal screening 